\title{
STUDI KOMPARATIF METODE COOPERATIVE LEARNING TIPE JIGSAW DAN METODE CERAMAH UNTUK MENINGKATKAN HASIL BELAJAR MAHASISWA PRODI D3 AKUNTANSI PADA MATA KULIAH AKUNTANSI BIAYA
}

\author{
Hikmatul Maulidah $^{1}$ dan Bahri Kamal ${ }^{2}$ \\ ${ }^{12}$ Program Studi D-III Akuntansi , Politeknik Harapan Bersama Tegal \\ e-mail: iimaulidah89@gmail.com
}

\begin{abstract}
Abstrak
Faktor yang mempengaruhi hasil belajar dibagi menjadi faktor internal dan faktor eksternal. Metode pembelajaran merupakan salah satu faktor eksternal yang dapat mempengaruhi hasil belajar. Metode pembelajaran yang dibahas dalam penelitian ini adalah metode cooperative learning tipe jigsaw dan metode ceramah. Permasalahan yang diangkat yakni adakah perbedaan hasil belajar akuntansi biaya dengan menggnakan metode pembelajaran cooperative learning tipe jigsaw dan metode pembelajaran ceramah pada mahasiswa Prodi D-III Akuntansi Politeknik Harapan Bersama Tegal semester 3. Tujuan penelitian ini adalah untuk mengetahui perbedaan hasil belajar antara penggunaan metode cooperative learning tipe jigsaw dengan metode pembelajaran ceramah pada mahasiswa Prodi D-III Akuntansi Politeknik Harapan Bersama Tegal semester 3. Sampel penelitian dibagi menjadi 2 kelas yaitu kelas A sebagai kelas eksperimen dan kelas B sebagai kelas kontrol. Pada kelas eksperimen diterapkan metode pembelajaran kooperatif tipe jigsaw sedangkan pada kelas kontrol diterapkan metode ceramah. Observasi/pengamatan, tes hasil belajar, dan dokumentasi menjadi beberapa metode pengumpulan data yang digunakan dalam penelitian ini. Sedangkan teknik analisis data menggunakan uji normalitas, uji hmogenitas, dan uji independent t-test. Hasil perhitungan data diperoleh $t$-test, Sig. (2-tailed) sebesar 0,004. Sig. (2-tailed) sebesar 0,004 lebih kecil dari 0,05 maka Ha diterima, hal ini menunjukkan bahwa ada perbedaan rata-rata hasil test yang signifikan antara kedua kelas. Berdasarkan hasil penelitian dapat disimpulkan ada perbedaan hasil belajar akuntansi biaya dengan menggunakan metode cooperative learning tipe jigsaw dan metode ceramah pada mahasiswa Prodi D-III Akuntansi Politeknik Harapan Bersama Tegal. Hasil belajar metode cooperative learning tipe jigsaw lebih baik dibandingkan dengan hasil belajar metode ceramah pada pokok bahasan analiss perilkau biaya. Saran penulis bahwa dosen perlu menambah wawasan dan pengetahuan tentang metode-metode pembelajaran yang inovatif sehingga proses pembelajaran akuntansi biaya akan lebih efektif.
\end{abstract}

Kunci: Metode Ceramah, Metode Cooperative Learning tipe Jigsaw, Hasil belajar.

\section{PENDAHULUAN}

Pendidikan adalah suatu usaha sadar dan terencana untuk mewujudkan suasana belajar dan proses pembelajaran agar peserta didik secara aktif mengembangkan potensi dirinya untuk memiliki kekuatan spiritual keagamaan, pengendalian diri, kepribadian, kecerdasan, akhlak mulia serta ketrampilan yang diperlukan dirinya, masyarakat, bangsa dan negara (Undang-undang Pendidikan Nomor 20/2003, pasal 1 ayat 1). Pendidikan diharapkan bisa menghasilkan peserta didik yang berkualitas dan berdaya saing agar tujuan utama pendidikan dalam mencerdaskan kehidupan bagsa dapat tercapai (Saputra, 2011). Begitupula halnya dengan pendidikan di perguruan tinggi yang selalu berusaha untuk meningkatkan kualitas pendidikan nasional demi mencerdaskan kehidupan bangsa. Salah satu yang menjadi indikator dalam pengukuran keberhasilan pendidikan di perguruan tinggi dapat dilihat dari hasil belajar mahasiswa. Djamarah dan Zain (2006) menyatakan bahwa "Apabila bahan pelajaran yang diajarkan 60\%-75\% nya dikuasai mahasiswa maka presentasi keberhasilan mahasiswa pada mata kuliah tersebut tergolong baik". Pada observasi awal yang dilakukan pada mahasiswa Prodi D3 Akuntansi Politeknik Harapan Bersama Tegal kelas 3A dan 3B tahun ajaran gasal 2019/2020 diperoleh data nilai quiz mata kuliah akuntansi biaya pokok bahasan analisis perilaku biaya yang menunjukkan masih banyak nilai mahasiswa kurang dari ketuntasan yaitu 75,00. 
Tabel 1.1 Nilai Quiz Mata Kuliah Akuntansi Biaya Pokok Bahasan Analisis Perilaku Biaya

\begin{tabular}{|c|c|c|c|c|c|}
\hline Kelas & $\begin{array}{c}\text { Nilai dibawah } \\
75\end{array}$ & $\%$ & $\begin{array}{c}\text { Nilai diatas } \\
75\end{array}$ & $\%$ & $\begin{array}{c}\text { Jumlah } \\
\text { Siswa }\end{array}$ \\
\hline 3A & 18 & 62.07 & 11 & 37,93 & 29 \\
\hline 3B & 20 & 64.51 & 11 & 35.48 & 31 \\
\hline Jumlah & 38 & 63.33 & 22 & 36.67 & 60 \\
\hline
\end{tabular}

Sumber: Data diolah tahun 2020

Nilai yang memenuhi standar ketuntasan sebesar $75 \%$ dari tabel di atas dapat dilihat hanya terdapat $36,67 \%$ mahasiswa, sedangan sisanya sebesar $63,33 \%$ mahasiswa memiliki hasil belajar yang belum tuntas pada pokok bahasan analisis perilaku biaya dalam mata kuliah akuntansi biaya. Hal ini diduga disebabkan oleh metode pembelajaran yang kurang bervariasi. Berdasarkan hasil observasi awal metode pembelajaran yang digunakan oleh dosen dalam pembelajaran adalah metode ceramah yang masih berorientasi penuh pada dosen (lecturer oriented). Salah satu kelemahan metode ceramah adalah sumber pembelajaran hanya dari dosen yang bersangkutan. Hal ini dapat membuat mahasiswa kurang diberi kesempatan untuk mengembangkan kreativitas dan belum terlibat dalam proses pembelajaran. Selain itu, keaktifan mahasiswa dalam proses pembelajaran tidak optimal karena sedikit mahasiswa yang berpartisipasi dalam proses pembelajaran sehingga dibutuhkan pengembangan metode pembelajaran untuk menghasilkan lingkungan pembelajaran yang dapat meningkatkan peran aktif dan hasil belajar mahasiswa mata kuliah akuntansi biaya.

Mata kuliah akuntansi biaya berfokus untuk mempelajari cara atau metode untuk mencatat, mengukur, hingga melaporkan informasi mengenai biaya-biaya yang digunakan selama proses produksi. Mata kuliah ini memberikan pengetahuan dan pemahaman tentang perhitungan pengumpulan produksi dan pengendalian biaya yang berguna bagi keputusan manajemen. Salah satu pokok bahasan dari mata kuliah akuntansi biaya adalah analisis perilaku biaya. Dalam pokok bahasan ini mahasiswa dituntut untuk konsentrasi secara penuh dalam proses pembelajaran, karena untuk dapat memahami materi ini mahasiswa harus benar-benar mengetahui jenis biaya dan metode perhitungan biaya. Materi ini sangat tepat apabila menggunakan metode pembelajaran cooperative learning tipe jigsaw, karena dalam mengerjakan atau memahami materi analisis perilaku biaya dapat didukung dengan team work, sehingga mahasiswa tidak merasa jenuh dalam proses pembelajaran. Dengan adanya team work mahasiswa dapat bertanya pada teman sekelompoknya yang telah berdiskusi dalam kelompok ahli, sehingga mereka benar-benar dapat memahami tentang materi analisis perilaku biaya.

Berdasarkan fenomena yang telah dipaparkan di atas dosen diharapkan dapat memberikan kontribusinya melalui metode pembelajaran yang diberikan kepada mahasiswa agar bisa meningkatkan partisipasi mahasiswa dalam proses pembelajaran sehingga dapat meningkatkan hasil belajar mahasiswa. Metode pembelajaran yang demikian disebut dengan metode pembelajaran kooperatif. Menurut Slavin (2008) pembelajaran kooperatif adalah model pembelajaran dengan setting kelompok - kelompok kecil dengan memperhatikan keberagaman anggota kelompok sebagai wadah siswa bekerjasama dan memecahkan suatu masalah melalui interaksi sosial dengan teman sebayanya, memberikan kesempatan pada peserta didik untuk mempelajari sesuatu dengan baik pada waktu yang bersamaan dan ia menjadi narasumber bagi teman yang lain.

Pembelajaran kooperatif (cooperative learning) memiliki berbagai tipe, salah satu diantaranya adalah tipe jigsaw. Motode pembelajaran ini didesain untuk meningkatkan rasa tanggung jawab mahasiswa terhadap pembelajarannya sendiri dan juga pembelajaran orang lain. Mahasiswa tidak hanya mempelajari pokok bahasan yang diberikan, tetapi mereka juga harus siap memberikan dan mengajarkan pokok bahasan tersebut kepada kelompoknya. Mahasiswa dibagi dalam beberapa kelompok belajar yang heterogen yang beranggotakan 5-6 orang dengan menggunakan pola kelompok asal dan kelompok ahli. Kelompok asal adalah kelompok awal mahasiswa terdiri dari berapa anggota kelompok ahli yang dibentuk dengan memperhatikan keragaman dan latar belakang. Dosen dituntut trampil dan mengetahui latar belakang siswa agar terciptanya suasana yang baik bagi setiap angota kelompok. Sedangkan kelompok ahli, yaitu kelompok mahasiswa yang terdiri dari anggota kelompok 
lain (kelompok asal) yang ditugaskan untuk mendalami pokok bahasan tertentu untuk kemudian dijelaskan kepada anggota kelompok asal.

Para anggota dari kelompok asal yang berbeda, bertemu dengan pokok bahasan yang sama dalam kelompok ahli untuk berdiskusi dan membahas materi yang ditugaskan pada masing-masing anggota kelompok serta membantu satu sama lain untuk mempelajari pokok bahasan mereka tersebut. Peran dosen adalah mefasilitasi dan memotivasi para anggota kelompok ahli agar mudah untuk memahami materi yang diberikan. Setelah pembahasan selesai, para anggota kelompok kemudian kembali pada kelompok asal dan mengajarkan pada teman sekelompoknya apa yang telah mereka dapatkan pada saat pertemuan di kelompok ahli. Para kelompok ahli harus mampu untuk membagi pengetahuan yang di dapatkan saat melakuakn diskusi di kelompok ahli, sehingga pengetahuan tersebut diterima oleh setiap anggota pada kelompok asal. Kunci cooperative learning tipe jigsaw ini adalah interdependence setiap mahasiswa terhadap anggota tim yang memberikan informasi yang diperlukan. Artinya mahasiswa harus memiliki tanggung jawab dan kerja sama yang positif dan saling ketergantungan untuk mendapatkan informasi dan memecahkan masalah yang diberikan. Penelitian ini menganalisis adakah perbedaan hasil belajar mata kuliah akuntansi biaya dengan menggunaan metode cooperative learning tipe jigsaw dan metode pembelajaran ceramah pada mahasiswa prodi D3 Akuntansi Politeknik Harapan Bersama. Melalui penelitian ini akan dibuat mekanisme pembelajaran dengan menggunakan dua metode pembelajaran yang diterapkan pada dua kelas yaitu kelas eksperimen dengan menggunakan metode cooperative learning tipe jigsaw dan kelas kontrol dengan menggunakan metode pembelajaran ceramah. Hasil belajar antara kelas eksperimen dan kelas kontrol akan dibandingkan untuk mengetahui apakah ada perbedaan hasil belajar antara metode pembelajaran kooperatif tipe Jigsaw dengan metode Ceramah.

\section{METODE}

Penelitian ini menggunakan pendekatan komparatif. Data dikumpulkan dengan teknik observasi dan tes. Observasi dalam penelitian ini dilakukan secara langsung dengan mengumpulkan data yang berkaitan dengan keperluan penelitian ini. Instrumen tes digunakan dengan tujuan untuk mengetahui hasil belajar mahasiswa terhadap pokok bahasan analisis perilaku biaya. Dalam penelitian ini, peneliti menggunakan teknik analisis data kuantitatif, yaitu data yang dapat diwujudkan dengan angka yang diperoleh dari lapangan. Adapun data kuantitatif ini dianalisis dengan menggunakan uji normalitas, uji homogenitas, dan uji independen $t$-test. Prosedur penelitian dilakukan sebagai berikut:

\section{Kelas Experiment}

a. Persiapan Didalam fase persiapan ini hal-hal yang dilakukan meliputi:

- Menyusun perangkat pembelajran seperti rencana pelaksanaan pembelajaran (RPP) beserta tujuan pembelajaran.

- Membuat lembar diskusi siswa beserta jawaban

- Merancang pembentukan kelompok.

b. Pelaksanaan Dalam fase pelaksanaan ini hal-hal yang didukung meliputi:

- Dosen menjelaskan proses jalannya pembelajaran menggunakan metode pembelajaran kooperatif tipe jigsaw.

- Siswa dibagi menjadi 6 kelompok asal, yang anggotanya setiap kelompok 7-8 orang, kemudian siswa dibagi kembali kedalam kelompok ahli yang anggotanya merupakan perwakilan 1 -2 siswa dari kelompok asal yang telah terbentuk. Kemudian kelompok ahli melakukan diskusi.

- Tiap kelompok ahli mendiskusikan materi yang telah diberikan dengan memberikan pertanyaan dalam lembar soal sebagai panduan diskusi.

- Dosen membimbing mahasiswa dalam pelaksanaan diskusi.

- Mahasiswa mempresentasikan yang telah mereka diskusikan di kelompok ahli kepada teman-temannya di kelompok asal.

c. Evaluasi

Setelah proses pembelajaran berakhir kemudian diadakan post tes berupa soal essay untuk mengetahui tingkat penguasaan materi analisis perilaku biaya 


\section{Kelas Kontrol}
a. Persiapan:
Menyusun perangkat pembelajaran seperti rencana seperti rencana pelaksanaan pembelajaran (RPP) beserta tujuan pembelajaran.
b. Pelaksanaan
- Guru menyajikan materi analisis perilaku biaya dengan pembelajaran ceramah
- Latihan dan tanya jawab soal.
c. Evaluasi:
Setelah proses pembelajaran berakhir kemudian diadakan postes berupa soal essay untuk mengetahui tingkat penguasaan materi analisis perilaku biaya.

\section{HASIL DAN PEMBAHASAN}

\section{Analisis Data}

a. Uji Normalitas

Data dari hasil penelitian terlebih dahulu diadakan uji prasyarat data sebelum data dianalisis. Hal ini dimaksudkan untuk mengetahui apakah data yang terkumpul memenuhi syarat untuk dianalisis atau tidak. Uji prasyarat analisis yang digunakan adalah uji normalitas. Hasil uji normalitas data hasil belajar dapat dilihat pada tabel 1 berikut ini:

Tabel 1 Hasil Uji Normalitas

\begin{tabular}{|l|r|r|r|r|r|rr|}
\hline & \multicolumn{6}{|c|}{ Kolmogorov-Smirnov } & \multicolumn{3}{|c|}{ Shapiro-Wilk } \\
\cline { 2 - 8 } & Statistic & Df & \multicolumn{1}{c|}{ Sig. } & Statistic & Df & \multicolumn{2}{c|}{ Sig. } \\
\hline $\begin{array}{l}\text { Hasil } \\
\text { Belajar }\end{array}$ &, 090 & 60 &, $200^{*}$ &, 966 & 60 & &, 093 \\
\hline
\end{tabular}

Sumber: Data diolah tahun 2020

Berdasarkan tabel 1 hasil kolmogrov-smirnov menunjukkan nilai signifikansi (p) sebesar 0,200. Tingkat signifikansi 0,200 lebih besar dari 0,05 sehingga dapat disimpulkan bahwa variabel telah terdistribusi secara normal

b. Uji Homogenitas

Uji ini bertujuan untuk mengetahui apakah kedua sampel homogen atau tidak homogen. Berdasarkan hasil uji homogenitas diperoleh hasil pada tabel 2

Tabel 2 Hasil Uji Homogenitas

\begin{tabular}{|ll|r|r|r|c|}
\hline & Levene Statistic & df1 & df2 & Sig. \\
\hline Hasil & Based on Mean &, 064 & 1 & 58 &, 801 \\
Belajar & Based on Median &, 079 & 1 & 58 &, 779 \\
& Based on Median and with &, 079 & 1 & 57,899 &, 779 \\
& adjusted df &, 066 & 1 & 58 &, 798 \\
& Based on trimmed mean & &
\end{tabular}

Sumber: Data diolah tahun 2020

Tabel 2 menunjukkan hasil uji homogenitas dengan metode Levene's Test. Nilai Levene ditunjukkan pada baris Nilai based on Mean, yaitu 0,064 dengan p value (sig) sebesar 0,801 di mana > 0,05 yang berarti terdapat kesamaan varians antar kelompok atau yang berarti homogen.

c. $\quad$ Uji Independen $t$-test

Uji independen t-test digunakan untuk mengetahui kemampuan atau hasil belajar mata kuliah akuntansi biaya mahasiswa setelah dilakukan perlakuan dengan metode yang berbeda. Kelompok esksperimen dengan penggunaan model pembelajaran kooperatif Tipe Jigsaw sedangkan kelompok kontrol dengan metode pembelajaran ceramah bervariasi. Dari hasil nilai ujian pokok bahasan analisis perilaku biayadi dapatkan hasil seperti tabel 3 
Tabel 3 Hasil Uji Independent t-test

\begin{tabular}{|c|c|c|c|c|c|c|c|c|c|c|}
\hline & \multicolumn{2}{|c|}{$\begin{array}{l}\text { Levene's } \\
\text { Test for } \\
\text { Equality of } \\
\text { Variances }\end{array}$} & \multicolumn{7}{|c|}{ t-test for Equality of Means } \\
\hline & & \multirow[b]{2}{*}{$\mathrm{F}$} & \multirow[b]{2}{*}{ Sig. } & \multirow[b]{2}{*}{$\mathrm{t}$} & \multirow[b]{2}{*}{ df } & \multirow{2}{*}{$\begin{array}{c}\text { Sig. } \\
\text { (2-tailed) }\end{array}$} & \multirow{2}{*}{$\begin{array}{c}\text { Mean } \\
\text { Difference }\end{array}$} & \multirow{2}{*}{$\begin{array}{l}\text { Std. Error } \\
\text { Difference }\end{array}$} & \multicolumn{2}{|c|}{$\begin{array}{c}95 \% \\
\text { Confidence } \\
\text { Interval of the } \\
\text { Difference }\end{array}$} \\
\hline & & & & & & & & & Lower & Upper \\
\hline $\begin{array}{l}\text { Hasil } \\
\text { Belajar }\end{array}$ & $\begin{array}{l}\text { Equal } \\
\text { varian } \\
\text { ces } \\
\text { assum } \\
\text { ed } \\
\text { Equal } \\
\text { varian } \\
\text { ces not } \\
\text { assum } \\
\text { ed }\end{array}$ &, 064 &, 801 & $\begin{array}{l}-2,981 \\
-2,990\end{array}$ & 58 & 更 & $-5,482$ & 1,839 & $-9,163$ & $-1,801$ \\
\hline
\end{tabular}

Sumber: Data diolah tahun 2020

Dari hasil perhitungan pada tabel 3 dengan uji independen t-test diperoleh Sig. (2-tailed) sebesar 0,004. Sig. (2-tailed) sebesar 0,004 lebih kecil dari 0,05 sehingga Ha diterima, maka dapat disimpulkan ada perbedaan hasil belajar mahasiswa yang menggunakan metode kooperatif tipe jigsaw dan hasil belajar mahasiswa yang menggunakan metode ceramah pada mata kuliah Akuntansi Biaya.

Tabel 4 Hasil Uji Independent t-test

\begin{tabular}{|c|c|c|c|c|c|}
\hline Kelas & & $\mathrm{N}$ & Mean & Std. Deviation & $\begin{array}{l}\text { Std. Error } \\
\text { Mean }\end{array}$ \\
\hline Hasil Belajar & 1,00 & 31 & 71,48 & 7,429 & 1,334 \\
\hline & 2,00 & 29 & 76,97 & 6,769 & 1,257 \\
\hline
\end{tabular}

Sumber: Data diolah tahun 2020

Berdasarkan tabel 4 kelompok dan kelompok kontrol memiliki kemampuan berbeda. Kelompok eksperimen memiliki kemampuan yang lebih baik dibandingkan dengan kemampuan kelompok kontrol. Karena hasil dari rata-rata untuk kelompok eksperimen penggunaan metode cooperatve learning tipe jigsaw diperoleh rata-rata nilai sebesar 76,97 sedangkan pada kelompok control dengan metode ceramah diperoleh hasil rata-rata sebesar 71,48 .

\section{Pembahasan}

Penggunaan metode pembelajaran yang tepat akan berpengaruh terhadap hasil belajar yang optimal. Metode cooperative learning tipe jigsaw dapat digunakan sebagai alternatif dalam proses belajar mengajar agar hasil belajar mahasiswa pada mata kuliah akuntansi biaya pokok bahasan analisis perilaku biaya menjadi lebih baik. Metode ini dapat meningkatkan keaktifan mahasiswa dalam proses pembelajaran, karena setiap mahasiswa memiliki peran dan tanggung jawab masingmasing, selain itu kerjasama antar anggota kelompok juga sangat diperlukan. Metode cooperative learning tipe jigsaw menekankan pada partisipasi dan aktivitas mahasiswa untuk mencari sendiri materi pokok bahasan. Metode ini menuntut para mahasiswa untuk memiliki kemampuan yang baik dalam berkomunikasi maupun dalam keterampilan proses kelompok. Setelah pemberian materi dan proses pembelajaran pada kelas eksperimen dan kelas kontrol selesai, langkah selanjutnya mahasiswa diberikan serangkaian test. Hasil test tersebut kemudian dianalisis, terlihat bahwa hasil belajar kelas 
eksperimen dan kelas kontrol memiliki perbedaan. Perbedaan hasil belajar antara kelas eksperimen dan kelas kontrol dapat terlihat dari rata-rata nilaiuntuk kelas eksperimen 76,97, sedangkan untuk kelas kontrol 71,48. Hal ini juga ditunjukkan dari hasil analisis uji independent t-test, Sig. (2-tailed) sebesar 0,004. Sig. (2-tailed) sebesar 0,004 lebih kecil dari 0,05 sehingga Ha diterima, maka dapat disimpulkan ada perbedaan hasil belajar mahasiswa yang menggunakan metode kooperatif tipe jigsaw dan hasil belajar mahasiswa yang menggunakan metode ceramah pada mata kuliah Akuntansi Biaya

Pembelajaran dengan menggunakan metode cooperative learning tipe jigsaw berpusat pada mahasiswa, sedangkan dosen hanya berperan sebagai fasilitator, motivator dan evaluator. Mahasiswa dituntut untuk dapat mengembangkan keterampilan, kreatifitas, kemampuan berpikir sendiri, berdiskusi dan belajar bersama dengan teman-teman satu kelompoknya yang dibentuk dalam sebuah tim. Berbeda dengan proses pembelajaran pada kelas kontrol yang menggunakan metode ceramah, hampir seluruh kegiatan pembelajaran dikendalikan oleh dosen. Dosen memegang peranan utama dalam kegiatan pembelajaran termasuk dalam menilai kemajuan mahasiswa. Hal ini membuat mahasiswa kurang aktif dalam bertanya dan merespon pertanyaan dari dosen.

Proses belajar akan berhasil apa bila mahasiswa bisa aktif pada saat proses pembelajaran sedang berlangsung. Hal ini juga diperkuat oleh penelitian terdahulu tetatang metode pembelajaran kooperatif tipe jigsaw yang dilakukan oleh Sihotang (2015) yang menunjukkan bahwa metode cooperative learning tipe jigsaw dapat meningkatkan hasil belajar mahasiswa. Berdasarkan analisis data dan pengujian data penelitian serta dengan melihat penelitian terdahulu yang relevan, dapat disimpulkan bahwa hasil belajar akuntansi biaya pokok bahasan analisis perilaku biaya yang menggunakan metode cooperative learning tipe jigsaw lebih baik jika dibandingkan dengan hasil belajar akuntansi biaya pokok bahasan analisis perilaku biaya dengan menggunakan metode ceramah pada siswa mahasiswa Prodi D3 Akuntansi Politeknik Harapan Bersama.

\section{PENUTUP}

Berdasarkan hasil analisis data dan pembahasan, maka dapat ditarik kesimpulan: Ada perbedaan hasil belajar mahasiswa yang metode cooperative learning tipe jigsaw dengan metode ceramah. Peneliti mengemukakan beberapa saran sebagai beikut:

1. Dosen perlu menambah wawasan dan pengetahuan tentang metode-metode pembelajaran yang inovatif, sehingga proses pembelajaran akuntansi biaya akan lebih efektif.

2. Dosen hendaknya mengimplementasikan metode cooperative learning tipe jigsaw sebagai salah satu variasi untuk dapat meningkatkan keaktifan mahasiswa dalam proses pembelajaran sebagai usaha perbaikan hasil belajar akuntansi khususnya pada pokok bahasan analisis perilaku biaya.

3. Dalam penggunaan metode cooperative learning tipe jigsaw, dosen perlu meningkatkan pemantauan terhadap mahasiswa selama proses diskusi berlangsung untuk menghindari terjadinya kegaduhan siswa yang timbul pada saat mahasiswa menjelaskan kepada mahasiswa lain pada kelompoknya yang belum paham dengan pokok bahasan.

\section{DAFTAR PUSTAKA}

Djamarah \& Zain. (2006). Strategi belajar mengajar. Jakarta: Rineka Cipta.

Handayani, Sri dan Sapir. 2009. Efektifitas Penerapan Model PembelajaranBerbasis Masalah (Problem Based Learning) dan Pembelajaran Kooperatif (cooperative Learnig) Tipe Jigsaw untuk Meningkatkan Aktivitas Belajar, Hasil Belajar dan Respon Belajar Siswa pada Mata Pelajaran Ekonomi di SMA Negeri 2 Malang. Jurnal Pendidikan Ekonomi (JPE), No.1 Vol.2. Hal 38-52

Saputra, Ilham Joko. 2011. Studi Komparasi Antara Metode Pembelajaran Kooperatif Tipe Jigsaw dengan Metode Ceramah Bervariasi Terhadap Hasil Belajar Akuntansi Materi Jurnal Penyesuaian pada Siswa Kelas XI IPS Madrasah Aliyah Negeri Purwodadi TA 2010/2011. Skripsi. Universitas Negeri Semarang. 
Sihotang, Ijah Mulyani. (2015). Model Pembelajaran Jigsaw dalam Upaya Meningkatkan Hasil belajar Akuntansi. Prosiding Seminar Nasional Pendidikan Akuntansi dan Keuangan. Pengembangan Pendidikan Akuntansi dan Keuangan yang Berkelanjutan

Slavin, E. Robert. 2008. Cooperative Learning: Teori, Riset, dan Praktik.(Penterjemah: Nurulita Yusron dan Dr. Zubaedi). Bandung: Nusa Indah

Sudjana, Nana. 2004. Dasar-dasar Proses Belajar Mengajar. Bandung: Sinar Baru Algesindo. Sugiyono. (2012). Metode Penelitian Bisnis, Bandung; CV Alfabeta.

Undang-Undang SISDIKNAS No. 20 Tahun 2003 